\title{
Meadows of the seagrass Posidonia oceanica are a significant source of organic matter for adjoining ecosystems
}

\author{
L. Cardona ${ }^{1,2, *}$, M. Revelles ${ }^{1}$, M. Sales ${ }^{3}$, A. Aguilar $^{1}$, A. Borrell ${ }^{1}$ \\ ${ }^{1}$ Department of Animal Biology, Faculty of Biology, University of Barcelona, 08029 Barcelona, Spain \\ ${ }^{2}$ Department of Experimental and Health Sciences, Faculty of Biology and Health Sciences, University Pompeu Fabra, \\ 08003 Barcelona, Spain \\ ${ }^{3}$ Centre d'Estudis Avançats de Blanes, CSIC, Camí Santa Bárbara s/n, 17300 Blanes, Spain
}

\begin{abstract}
Stable isotopes of carbon and nitrogen were used to assess the relevance of 4 primary carbon sources (the macroalga Cystoseira balearica, decaying blades of the seagrass Posidonia oceanica, seagrass epiphytes and pelagic particulate organic matter [POM]) for consumers inhabiting 3 adjoining subtidal habitats in the Western Mediterranean: seagrass meadows, unvegetated sandy patches and the overlying pelagic ecosystem. MANOVA and ANOVA revealed statistically significant differences between the $\delta^{13} \mathrm{C}$ signal of decaying blades of $P$. oceanica $(-13.0 \pm 0.6 \%)$, epiphytes $(-19.7 \pm 0.4 \%)$ and a third group including POM $(-23.1 \pm 0.3 \%)$ and C. balearica $(-22.7 \pm 0.8 \%)$. However, these primary sources did not differ in their $\delta^{15} \mathrm{~N}$ signals (average: $1.0 \%$; range: 0.8 to $1.2 \%$ ). IsoSource mixing model software was used to calculate the contribution of each primary source to the carbon assimilated by each animal species. Nested ANOVA showed that the 3 trophic webs differed in the average contribution of the decaying blades of $P$. oceanica to the carbon assimilated by animals. The average contribution was $46.0 \pm 14.0 \%$ for meadow-dwelling species, $18.3 \pm$ $6.0 \%$ for sand-dwelling species and $12.8 \pm 3.0 \%$ for pelagic species, once zooxanthellae-bearing jellyfish were removed from the analysis. However, IsoSource provided solutions for all the pelagic species and for half the sand-dwelling species that do not use decaying blades of $P$. oceanica as a carbon source. Conversely, IsoSource identified the decaying blades of $P$. oceanica as a relevant carbon source in all the solutions calculated for 3 different sand-dwelling species and in all of the meadowdwelling species. Thus, we conclude that organic detritus from $P$. oceanica is a relevant carbon source for species inhabiting seagrass meadows and for those sand-dwelling species living close to the meadows, but not for species exploiting deeper and more distant unvegetated patches.
\end{abstract}

KEY WORDS: Detritus · Export · Seagrass meadows $\cdot$ Stable-isotope analysis

Resale or republication not permitted without written consent of the publisher

\section{INTRODUCTION}

Phytoplankton is the primary source of carbon in most marine ecosystems (Duarte \& Cebrián 1996), although benthic macrophytes are also known to make significant carbon contributions to coastal ecosystems such as kelp forests (Duggins et al. 1989), seagrassmangrove systems (Paterson \& Whitfield 1997) and salt marshes (Currin et al. 1995, but see Créach et al. 1997). The relevance of macrophyte debris for the trophic webs of unvegetated areas is often much lower than that of phytoplankton (Loneragan et al. 1997, Vetter and Dayton 1999, Polunin et al. 2001), but macrophyte debris may fuel secondary production even in deep, unvegetated ecosystems (Suchanek et al. 1985).

Large seagrass beds exist in the Western Mediterranean off the Balearic archipelago, Corsica and Sardinia, despite the decline of this ecosystem in most of the region throughout the 20th century (Procaccini et al. 2003). The primary production of these meadows is 
extremely high (Cebrián et al. 1997), but only a small fraction of it is consumed by local herbivores (Cebrián et al. 1996; Mateo \& Romero 1997, but see Tomas et al. 2005); most of it is actually exported as fine detritus or coarser debris to adjoining ecosystems, where it is thought to fuel detritus-based food webs (Boudouresque et al. 1994), although reliable evidence is lacking. This export process is thought to be more important in the unvegetated sandy patches scattered within the meadows and adjoining the lower fringe of the meadows than elsewhere (Boudouresque et al. 1994). However, the relevance of seagrass detritus as a carbon source for unvegetated areas close to the seagrass beds has never been carefully investigated, despite recent efforts devoted to assessing the relevance of several carbon sources in the food webs of Mediterranean ecosystems (Dauby 1989, Jennings et al. 1997, Lepoint et al. 2000, Polunin et al. 2001, Sarà et al. 2003, Vizzini \& Mazzola 2003).

The aim of the present study was to assess the relative contributions of phytoplankton, macroalgae, decaying blades of the seagrass Posidonia oceanica and its epiphytes to the secondary production of seagrass beds, the adjoining sandy patches and the overlying pelagic ecosystem.

\section{MATERIALS AND METHODS}

Study area. The samples were collected off Majorca and Minorca (Balearic archipelago), one of the most oligotrophic areas in the Western Mediterranean. The region receives negligible freshwater runoff and is not affected by upwelling processes (Emelyanov 1972, Cruzado 1985, Salat 1996). The highly transparent water allows development of extensive meadows of the seagrass Posidonia oceanica in areas shallower than $35 \mathrm{~m}$ (Procaccini et al. 2003).

Most of the samples were collected off northern Minorca in 2003, along the $20 \mathrm{~km}$ stretch of coastline between Bledes Islands and Addaia Bay (Fig. 1). Only sea turtles, marine birds and marine mammals were collected from other areas off Minorca and Majorca. It should be noted that the 2 islands share a common continental shelf and that marine mammals, marine birds and sea turtles move freely between them (Triay 2002, Cardona et al. 2005, Gonzalvo \& Aguilar in press).

The infralittoral landscape off northern Minorca is characterized by a patch mosaic of rock and sand, although rock prevails. Macroalgae cover infralittoral rocks shallower than $10 \mathrm{~m}$, and the seagrass Posidonia oceanica replace them in deeper areas, except on vertical walls. $P$. oceanica also grows in sandy areas shallower than $35 \mathrm{~m}$, although large unvegetated patches
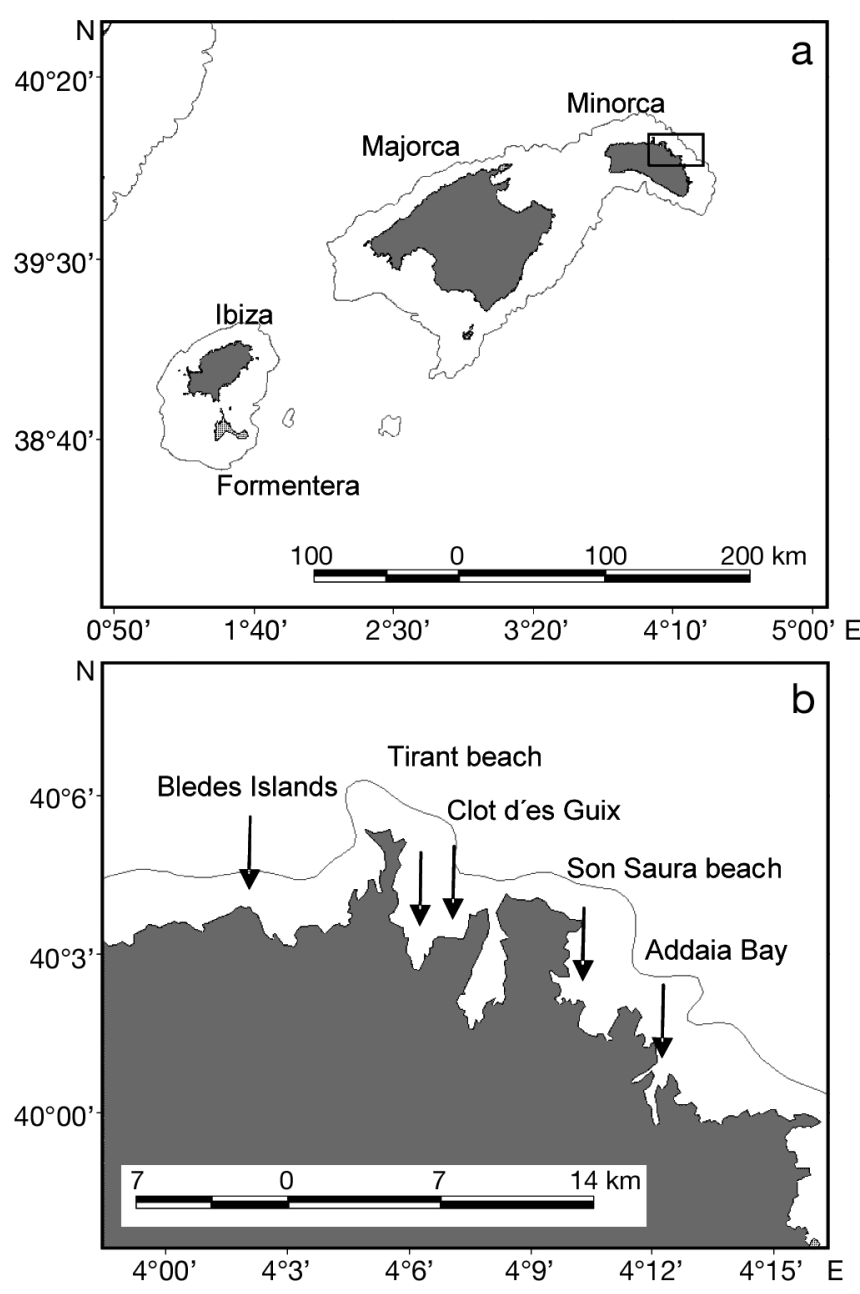

Fig. 1. Maps of the sampling areas. (a) The Balearic archipelago, showing the $-200 \mathrm{~m}$ isobath and the area of northern Minorca where most of the samples were collected. (b) Northern Minorca, showing the $-50 \mathrm{~m}$ isobath and the location of study sites

occur off Tirant beach, Clot de's Guix and Son Saura beach (Fig. 1).

Sampling. Decaying blades of Posidonia oceanica were collected in August 2003 from 5 different sandy patches (average depth $=22 \mathrm{~m}$ ) using SCUBA diving equipment. The 2 most distant sampling sites were $7 \mathrm{~km}$ apart. The decaying leaves from each site were pooled to form a single sample. Live blades of $P$. oceanica were collected in the adjoining meadows (average depth $=18 \mathrm{~m}$ ) to analyze the associated epiphytes, which were removed with a scalpel. Again, the epiphytes from several blades from the same meadow were pooled and treated as a single sample. A water sample (5 l) was collected over each sampling site (average depth $5 \mathrm{~m}$ ) and filtered through a $60 \mu \mathrm{m}$ net to remove copepods and large debris. The remaining particulate organic matter (POM), includ- 
ing phytoplankton and fine detritus, was collected on a precombusted GF/C filter of known dry weight; each filter was analyzed and treated as a replicate. The brown seaweed Cystoseira balearica, which dominates the infralittoral algal community on rocks shallower than $14 \mathrm{~m}$, was collected at 5 different sites (average depth $=8 \mathrm{~m}$ ) to characterize the isotopic signature of benthic macroalgae. Jellyfish were collected with a scoop net from a boat in April 2003 (Pelagia noctiluca, Salpa sp. and Velella velella) and August 2003 (Cotylorhiza tuberculata). All the fish species were collected from April to August 2003. Most of the fish species inhabiting seagrass meadows (Coris julis, Diplodus annularis, Diplodus vulgaris, Sarpa salpa, Scorpaena porcus, Serranus scriba and Symphodus tinca) were caught with hook and line; the only exceptions were saupe Sarpa salpa and scorpion fish Scorpaena porcus, which were caught with trammel nets. Fish from adjoining sandy bottoms shallower than $40 \mathrm{~m}$ (Bothus podas, Cephalacanthus volitans, Mullus surmuletus, Trachinus draco and Xyrichthys novacula) were caught with trammel nets. Pelagic zooplanktivorous fish pilchard Sardina pilchardus were caught with a purse seine, whereas ichthyophagous pelagic fish blue-fin tuna Thunnus thynnus were caught with hook and line. The marine birds osprey Pandion haliaetus and shag Phalacrocorax aristotelis were sampled opportunistically as dead nestlings. A nestling of $P$. haliaetus was sampled in the area in 2002. Two nestlings of $P$. aristotelis were sampled in Majorca and Minorca during the period 2002 to 2003. Stranded and bycatch specimens of the sea turtle Caretta caretta were sampled opportunistically in Majorca and Minorca during the period 2001 to 2004. Stranded specimens of the mammals striped dolphin Stenella coeruleoalba and bottle-nose dolphin Tursiops truncantus were sampled opportunistically in Majorca and Minorca during the period 1995 to 2004 .

Stable isotope analyses. All samples were stored at $-20^{\circ} \mathrm{C}$ until they were processed. Jellyfish were analyzed whole. Samples of fish consisted of a small piece of dorsal white muscle, while those of the other vertebrates consisted of muscle. After oven drying at $60^{\circ} \mathrm{C}$ to constant weight, all samples were ground to fine powder, their lipids extracted with a chloroform: methanol solution $(2: 1)$, and dried again. Although lipids come from the diet, they are more depleted in ${ }^{13} \mathrm{C}$ than other tissues (DeNiro \& Epstein 1977), and seasonal variations in the amount of stored lipids may have a disproportionate impact on the $\delta^{13} \mathrm{C}$ of organisms. Epiphyte samples were split into 2 subsamples and one of them was also treated with $0.05 \mathrm{M} \mathrm{HCl}$ to remove the calcium carbonate from the calcareous algae (Ogawa \& Ogura 1997).
Once processed, samples were placed in tin weighing boats, weighed, combusted at $1000^{\circ} \mathrm{C}$, and their $\mathrm{C}$ and $\mathrm{N}$ stable isotopes analyzed in a Flash 1112 IRMS Delta C Series EA Thermo Finnigan continuous flow isotope ratio mass spectrometer. Stable isotope abundances were expressed in $\delta$ notation according to:

$$
\delta X=[(R \text { sample } / R \text { standard })-1] \times 1000
$$

where $X$ is ${ }^{13} \mathrm{C}$ and $R$ is the corresponding ratio ${ }^{13} \mathrm{C} /{ }^{12} \mathrm{C} . R_{\text {standard }}$ for ${ }^{13} \mathrm{C}$ is the Vienna Pee Dee Belemnite (VPDB) standard.

Isotopic models. The IsoSource version 3.1 software package (Phillips \& Gregg 2003) was used to calculate the contribution of the 4 primary sources to the carbon assimilated by each species. The model parameters are the isotope ratios of the potential food sources, the isotope ratio of the focal species and the trophic shift for carbon and nitrogen from prey to predator. Only Salpa sp. (Andersen \& Nival 1988), Cotylorhiza tuberculata (Pérez-Ruzafa et al. 2002) and Sarpa salpa (Peirano et al. 2001) forage directly on the primary sources, while the remaining jellyfish (Malej 1989) and fish (Roux 1986, Cardinale et al. 1997, Morte et al. 1999, Stergiou \& Karpouzi 2002) are carnivores. This is also true for all the marine birds (Francour \& Thibault 1996, Oro \& Ruiz 1997), turtles (Tomás et al. 2001) and dolphins (Aguilar 2000, Blanco et al. 2001). Hence, the trophic shift for $\delta^{13} \mathrm{C}$ between the primary producers (primary carbon sources) and the focal species was calculated by multiplying the average shift per trophic level in marine coastal trophic webs $(0.8 \%$, in agreement with France \& Peters 1997) by the number of trophic levels between primary producers and the species considered. The trophic level of species $i\left(\mathrm{Tl}_{i}\right)$ was calculated as:

$$
\mathrm{Tl}_{i}=1+\left(\delta^{15} \mathrm{~N}_{i}-\delta^{15} \mathrm{~N}_{\mathrm{p}}\right) / \Delta \delta^{15} \mathrm{~N}
$$

where $\delta^{15} \mathrm{~N}_{i}$ is the isotope ratio of species $i, \delta^{15} \mathrm{~N}_{\mathrm{p}}$ is the average isotope ratio of the primary producers $(1 \%$, see below), and $\Delta \delta^{15} \mathrm{~N}$ is the trophic shift for $\mathrm{N}$ per trophic level $(3.4 \%$, in agreement with Minagawa \& Wada 1984).

Statistical analyses. Multivariate analysis of variance (MANOVA) with 4 fixed factors (decaying blades of Posidonia oceanica, epiphytes, POM and Cystoseira balearica) was used to test whether the 4 sources considered shared a common bivariate isotopic signal. One-way univariate analysis of variance (ANOVA) with 4 fixed factors (decaying blades of P. oceanica, epiphytes, POM and C. balearica) was used as a post hoc test for assessing the contribution of $\delta^{13} \mathrm{C}$ and $\delta^{15} \mathrm{~N}$ to the differences in the bivariate isotopic signal revealed by MANOVA.

IsoSource was not run for of each species, but independently for each specimen (sample). Nested analysis 
of variance (ANOVA) with 3 (food web) $\times 22$ (species) fixed factors, followed by a post hoc Tukey's test, was then performed to test the hypothesis that the 3 food webs considered here differ in the average contribution of seagrass-derived carbon. The same analysis was conducted excluding the zooxanthellae-bearing jellyfish $(3 \times 20$ fixed factors).

Lilliefors' test was used to assess normality of samples before the tests were conducted, and Levene's test was used for assessing homoscedasticity. Data are always reported as mean $\pm \mathrm{SD}$, unless otherwise stated. All statistical analyses were conducted with the SPSS 11.5 software package.

\section{RESULTS}

The mean isotopic signals of the carbon sources considered here are shown in Table 1. MANOVA revealed the existence of statistically significant differences (Pillai's trace $=1 ; F_{6,32}=$ $19599.732 ; \mathrm{p}<0.001$ ) in the isotopic signal of the primary sources of carbon considered here, but they were due only to $\delta^{13} \mathrm{C}$ (ANOVA; $F_{3,16}=536.781$; $\mathrm{p}<0.001)$, as differences in $\delta^{15} \mathrm{~N}$ were not statistically significant (ANOVA; $F_{3,16}=1.558 ; \mathrm{p}=0.238$ ). Furthermore, a post hoc Tukey's test indicated that (1) POM and Cystoseira balearica did not differ in their average $\delta^{13} C_{1}(2)$ epiphytes were significantly more enriched in ${ }^{13} \mathrm{C}$ than POM and C. balearica, and (3) the decaying blades of $P$. oceanica were the most enriched of the 4 sources. Despite the absence of statistically significant differences between the $\delta^{13} \mathrm{C}$ of POM and that of C. balearica, they were not combined when running IsoSource. The implications of this similarity are discussed below.

The isotopic signals of the animals species considered here are reported in Table 2 . There was a positive

Table 1. Mean isotopic signatures of 4 sources (SD in parentheses)

\begin{tabular}{|lccc|}
\hline & $\mathrm{n}$ & $\delta^{13} \mathrm{C}$ & $\delta^{15} \mathrm{~N}$ \\
\hline POM & $5^{\mathrm{a}}$ & $-23.1(0.3)$ & $0.8(0.4)$ \\
Cystoseira balearica & 5 & $-22.7(0.8)$ & $1.2(0.3)$ \\
Epiphytes & $5^{\mathrm{a}}$ & $-19.7(0.4)$ & $1.0(0.3)$ \\
Posidonia oceanica (decaying blades) & 5 & $-13.0(0.6)$ & $1.0(0.3)$ \\
${ }^{\mathrm{a}}$ Collective samples including several individuals & \\
\hline
\end{tabular}

correlation between $\delta^{13} \mathrm{C}$ and $\delta^{14} \mathrm{~N}$, resulting in an overall increase of $\delta^{13} \mathrm{C}$ with trophic level (Fig. 2).

The mean contribution of each source to the carbon assimilated by each animal species and the range of possible solutions provided by IsoSource are reported in Table 3. Each individual solution is a combination of source proportions which satisfy mass balance in the mixing model and all them are equally feasible. Note that for most species, the actual contribution of epiphytes is uncertain, as the range of possible solutions is extremely wide, often from 0 to $>60 \%$. Furthermore, as POM and Cystoseira balearica did not differ in their isotopic signal, discrimination between them is biologically meaningless, although mathematically possible. Thus, the only relevant information provided by IsoSource is the contribution of decaying blades of Posidonia oceanica.

The average contribution of decaying Posidonia oceanica to the carbon assimilated by the 9 meadow-dwelling species was 46.0 $\pm 14.0 \%$. Furthermore, all of the possible 
solutions calculated by IsoSource for the 9 species included decaying $P$. oceanica as a carbon source contributing at least $4 \%$ of the assimilated carbon, but usually more than $32 \%$. The average contribution of decaying $P$. oceanica to the carbon assimilated by the 6 sand-dwelling species was $18.3 \pm 6.0 \%$, but for 3 of

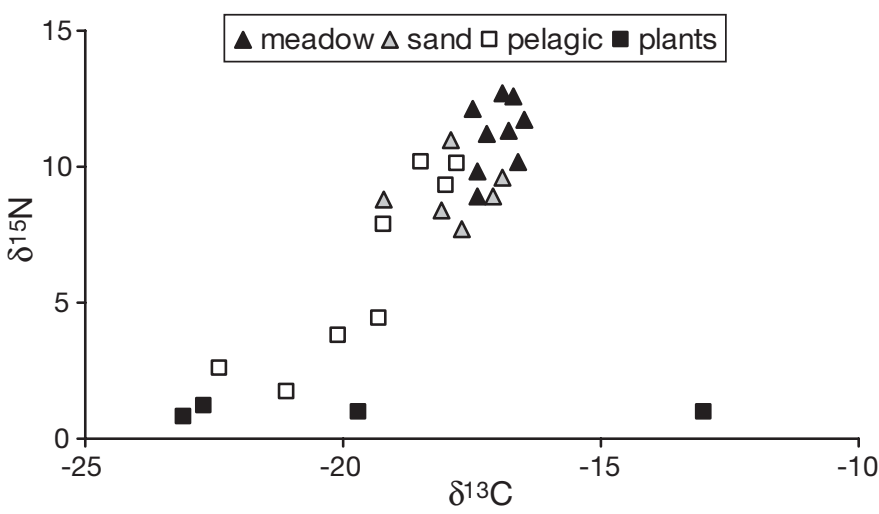

Fig. 2. Relationship between $\delta^{13} \mathrm{C}$ and $\delta^{15} \mathrm{~N}$, in the food webs considered. $\mathrm{r}^{2}=0.556(\mathrm{p}<0.001)$ when plants are excluded

Table 3. Mean contribution (\%) of 4 primary sources to the carbon assimilated by animal species from Posidonia oceanica meadows, adjoining sandy patches and the overlying pelagic ecosystem. Values in parentheses are the ranges of possible solutions provided by IsoSource

\begin{tabular}{|lcccc|}
\hline & POM & $\begin{array}{c}\text { Cystoseira } \\
\text { balearica }\end{array}$ & Epiphytes & $\begin{array}{c}\text { Posidonia } \\
\text { oceanica }\end{array}$ \\
\hline Meadow & & & & \\
Coris julis & $10(0-19)$ & $11(0-19)$ & $19(0-48)$ & $60(50-66)$ \\
Diplodus annularis & $10(0-20)$ & $9(0-22)$ & $33(2-60)$ & $48(39-58)$ \\
Diplodus vulgaris & $12(0-23)$ & $14(0-24)$ & $28(2-66)$ & $46(34-55)$ \\
Pandion haliaetus & $14(0-30)$ & $13(0-31)$ & $47(0-85)$ & $27(14-42)$ \\
Phalacrocorax aristotelis & $16(0-34)$ & $15(1-34)$ & $50(1-95)$ & $19(4-35)$ \\
Sarpa salpa & $12(0-22)$ & $12(0-23)$ & $30(2-63)$ & $47(36-56)$ \\
Scorpaena porcus & $9(0-21)$ & $9(0-21)$ & $39(0-57)$ & $52(43-62)$ \\
Serranus scriba & $10(0-20)$ & $10(0-18)$ & $25(0-54)$ & $56(46-64)$ \\
Symphodus tinca & $10(0-21)$ & $9(0-18)$ & $28(0-54)$ & $54(45-63)$ \\
Sand & & & & \\
Bothus podas & $15(0-33)$ & $15(1-33)$ & $48(0-91)$ & $23(8-38)$ \\
Cephalacanthus volitans & $17(0-32)$ & $18(0-30)$ & $37(0-83)$ & $23(12-41)$ \\
Mullus surmuletus & $21(7-36)$ & $21(8-39)$ & $46(0-82)$ & $12(0-27)$ \\
Trachinus draco & $18(1-36)$ & $18(1-37)$ & $49(0-94)$ & $15(0-31)$ \\
Tursiops truncatus & $21(7-36)$ & $21(8-39)$ & $46(0-82)$ & $12(0-27)$ \\
Xyrichthys novacula & $14(0-30)$ & $14(0-32)$ & $48(1-89)$ & $25(11-40)$ \\
Pelagic & & & & \\
Caretta caretta & $18(2-35)$ & $18(3-37)$ & $51(1-92)$ & $14(0-30)$ \\
Cotylorhiza tuberculata & $12(0-27)$ & $11(0-26)$ & $40(0-72)$ & $33(27-51)$ \\
Pelagia noctiluca & $27(15-41)$ & $27(17-41)$ & $36(0-66)$ & $10(0-22)$ \\
Salpa sp. & $33(22-43)$ & $34(21-43)$ & $23(1-53)$ & $10(0-17)$ \\
Sardina pilchardus & $30(18-40)$ & $31(16-42)$ & $29(0-64)$ & $12(0-21)$ \\
Stenella coeruleoalba & $21(3-37)$ & $21(1-35)$ & $41(0-94)$ & $18(0-31)$ \\
Thunnus thynnus & $28(15-40)$ & $28(12-39)$ & $31(1-71)$ & $13(0-23)$ \\
Velella velella & $18(0-35)$ & $19(0-32)$ & $43(1-98)$ & $20(2-34)$ \\
& & & & \\
\hline
\end{tabular}

them (Mullus surmuletus, Trachinus draco and Tursiopsis truncatus) IsoSource provided solutions not including $P$. oceanica. All the possible solutions calculated by IsoSource for the remaining 3 species (Bothus podas, Cephalacanthus volitans and Xyrichthys novacula) included decaying $P$. oceanica as a carbon source supplying at least $8 \%$ of the assimilated carbon. Finally, the average contribution of $P$. oceanica to the carbon assimilated by the 8 pelagic species was $16.3 \pm$ $7.6 \%$. However, IsoSource provided solutions not including $P$. oceanica for most of them. The only exceptions were the zooxanthellae-bearing jellyfish Cotylorhiza tuberculata and Velella velella. This suggests that zooxanthellae, and not decaying $P$. oceanica, are the main source of ${ }^{13} \mathrm{C}$ for these jellyfish. When these 2 species were removed from the analysis, the average contribution of $P$. oceanica to the pelagic food web was $12.8 \pm 3.0 \%$, although solutions not including $P$. oceanica were found for all of the species (Table 3).

Nested ANOVA revealed statistically significant differences in the average contribution of seagrassderived carbon to the carbon assimilated by the members of the 3 food webs, although differences also existed between species from the same food web (Table 4). A post hoc Tukey's test revealed differences only between the seagrass food web and the other two. However, when the zooxanthellae-bearing jellyfish Cotylorhiza tuberculata and Velella velella were removed from the analysis (Table 4), Tukey's test revealed differences in the average contribution of seagrass-derived carbon to the 3 trophic webs.

\section{DISCUSSION}

The use of stable isotopes as diet traces is a powerful technique, but interpreting the results is not always easy. The first shortcoming of the method is that the fractionating factor at any given age and feeding regime has to be known for each species (Fantle et al. 1999, Vanderklift \& Ponsard 2003, Gaye-Siessegger et al. 2004). However, obtaining laboratory-derived values for all the members of a food web is a monumental and probably unrealistic task. The only alternative is to derive standard values from a discrete number of laboratory studies (Minagawa \& Wada 1984, France \& Peters 1997). 
Table 4. Summary of the results of nested ANOVA to test the contribution of trophic level and species to variability in the contribution of the seagrass Posidonia oceanica to carbon assimilated by animal species from 3 different trophic webs (seagrass meadows, sandy bottoms and pelagic) when zooxanthellaebearing jellyfish are included in, or excluded from, the analysis. $r^{2}=0.950$; $\mathrm{p}<0.001$ in all cases

\begin{tabular}{|lrrrrc|}
\hline & SS & df & MS & $F$ & $p$ \\
\hline Jellyfish included & & & & & \\
Model & 60008.397 & 22 & 2727.654 & 173.915 & $<0.001$ \\
Instersect & 90470.600 & 1 & 90470.600 & 5768.381 & $<0.001$ \\
Trophic web & 20249.793 & 2 & 10124.897 & 645.561 & $<0.001$ \\
Species (Trophic level) & 10177.698 & 20 & 508.885 & 32.446 & $<0.001$ \\
Error & 2823.099 & 180 & 15.684 & & \\
Total & 233612.500 & 203 & & & \\
Jellyfish excluded & & & & & \\
Model & 59033.381 & 19 & 3107.020 & 181.089 & $<0.001$ \\
Instersect & 81768.509 & 1 & 81768.509 & 4765.787 & $<0.001$ \\
Trophic web & 30853.684 & 2 & 15426.842 & 899.136 & $<0.001$ \\
Species (Trophic level) & 6133.383 & 17 & 360.787 & 21.028 & $<0.001$ \\
Error & 2779.499 & 162 & 17.157 & & \\
Total & 218081.500 & 182 & & & \\
& & & & &
\end{tabular}

needed to test this hypothesis. Whatever the reason for the geographic differences, discrimination between the $\delta^{13} \mathrm{C}$ signal of POM, C. balearica and epiphytes was difficult off $\mathrm{Mi}$ norca and impeded the derivation of straightforward conclusions about their individual contributions as carbon sources for the animal species considered. Conversely, the $\delta^{13} \mathrm{C}$ signal of decaying $P$. oceanica was easily discriminated.

The use of nitrogen did not improve discrimination between POM, epiphytes and Cystoseira balearica, as all them had extremely similar $\delta^{15} \mathrm{~N}$ signals. The use of sulfur might potentially improved discrimination, as it is one of the most conservative of stable isotopes through trophic levels (McCutchan et al. 2003). In addition, one would expect very different $\delta^{34} \mathrm{~S}$

The second shortcoming is that mixing models yield reliable results only when large differences exist between the isotopic signals of the sources considered. Previous studies of food webs in vegetated areas of the Mediterranean showed that seagrasses are usually more enriched in ${ }^{13} \mathrm{C}$ than phytoplankton, whereas the isotopic signatures of macroalgae and epiphytes are often intermediate between those of seagrasses and phytoplankton (Dauby 1989, Jennings et al. 1997, Lepoint et al. 2000, Pinnegar \& Polunin 2000, Sarà et al. 2003, Vizzini et al. 2003). However, the $\delta^{13} \mathrm{C}$ signal of the largest, slow-growing macroalgae is often closer to that of phytoplankton than to that of seagrasses (Dauby 1989, Lepoint et al. 2000, Pinnegar \& Polunin 2000, but see Jennings et al. 1997).

The results we report agree with the pattern above, as the $\delta^{13} \mathrm{C}$ signal of the macroalga Cystoseira balearica was closer to that of phytoplankton than to that of the decaying blades of the seagrass Posidonia oceanica, as reported for northwestern Corsica (Dauby 1989, Pinnegar \& Polunin 2000). However, in southwestern Majorca, the $\delta^{13} \mathrm{C}$ signal of $C$. balearica was closer to that of $P$. oceanica than to that of plankton (Jennings et al. 1997). Likewise, the $\delta^{13} \mathrm{C}$ signal of epiphytes from southwestern Majorca was closer to those of C. balearica and P. oceanica than to that of plankton (Jennings et al. 1997), but in Minorca (this study) and northwestern Corsica the $\delta^{13} \mathrm{C}$ signal of epiphytes was closer to that of $C$. balearica and plankton than to that of P. oceanica (Dauby 1989, Lepoint et al. 2000, Pinnegar \& Polunin 2000). Those differences might partially reflect differences in the species composition of the epiphytic community, although further research is signals for plants exposed to anoxic sediments (seagrasses and their epiphytes) than for phytoplankton or reef macroalgae such as $C$. balearica. The former are expected to have a signal close to sulfide, due to contact with anoxic sediments, whereas the latter would probably have a signal close to sulfate (Michener \& Schell 1994, Tomas et al. 2006). Hence, sulfur might be useful for assessing the actual relevance of epiphytes as a carbon source for the animal species considered, but not for discriminating between the contribution of phytoplankton and that of reef macroalgae.

Fortunately, the $\delta^{13} \mathrm{C}$ signal of the decaying blades of Posidonia oceanica was different enough from those of the other 3 sources for us to conclude that $P$. oceanica is a relevant source of organic carbon not only for the meadow-dwelling species, but also for some sanddwelling species. Previous studies were unable to assess the relative importance of $P$. oceanica due to the impossibility of discriminating between benthic sources of carbon (Jennings et al. 1997), or they concluded that $P$. oceanica is only a minor source of organic carbon, simply because secondary consumers are more depleted in ${ }^{13} \mathrm{C}$ than $P$. oceanica, but without any further analysis (Dauby 1989, Lepoint et al. 2000; Pinnegar \& Polunin 2000). However, when IsoSource is used (this study), P. oceanica emerges as a major contributor to the carbon assimilated by the seagrassdwelling species, although it is not the primary source. Even marine birds whose feeding grounds are not restricted to seagrass beds, like Pandion haliaetus and Phalacrocorax aristotelis, indirectly derived from $P$. oceanica about $20 \%$ of the carbon they assimilated as nestlings. This is an extremely relevant finding, as 
$P$. haliaetus and P. aristotelis are endangered throughout the Mediterranean Sea (Mejías \& Amengual 2000) and hence any decline in the extension of seagrass beds may have a negative impact on breeding success.

IsoSource also revealed the relevance of decaying Posidonia oceanica for some sand-dwelling species whose habitat is restricted to infralittoral unvegetated sandy areas (Massutí et al. 1996). Sandy patches adjoining the $P$. oceanica meadows are significant fishing grounds for artisanal fishermen in autumn and winter when the lobster fishery is closed (Iglesias et al. 1994). They also support an important summer recreational fishery that targets Xyrichthys novacula (Riera \& Linde 2001). Also, some bottom trawlers fish year round for sand-dwelling species living close to the $P$. oceanica meadows (Reñones et al. 1995). A reduction in the amount of detritus reaching sandy patches from seagrass beds will have a negative impact on all of these fisheries. Conversely, there is only weak evidence that $P$. oceanica contributes to the carbon assimilated by species inhabiting the infralittoral and circalittoral (Massutí et al. 1996, Gonzalvo \& Aguilar in press). This indicates a rapid decline in the relevance of decaying $P$. oceanica as distance from the meadows increases, in agreement with Polunin et al. (2001), who pointed out the existence of a single source of organic carbon (phytoplankton) for the trophic web of the lower shelf and the upper and mid slope off the Balearic Archipelago.

A final, unexpected result was the contribution of decaying Posidonia oceanica to the carbon assimilated by pelagic species. Although seagrass detritus may sometimes occur in the water column (Dauby et al. 1995), thus allowing pelagic species to gain access to a ${ }^{13} \mathrm{C}$ enriched source of organic matter, this must be treated with considerable caution for a number of reasons. Firstly, IsoSource provided for most of the pelagic species solutions that did not include $P$. oceanica. The only exceptions were 2 zooxanthellae-bearing jellyfish, namely Cotylorhiza tuberculata and Velella velella (Kikinger 1986, Banaszak et al. 1993). Although phytoplankton comprise the bulk of the diet of $C$. tuberculata (Pérez-Ruzafa et al. 2002), zooxanthellae might be a more likely alternative source of ${ }^{13} \mathrm{C}$ enriched organic matter than decaying $P$. oceanica. Secondly, some of the pelagic species considered here, like Thunnus thynnus, are migratory and may have access to other sources enriched in ${ }^{13} \mathrm{C}$ when they visit other areas. These alternative sources are unknown, but a terrestrial origin is unlikely, as Mediterranean terrestrial plants are depleted in ${ }^{13} \mathrm{C}$ compared to most marine plants (Dauby 1989). Clearly, the issue deserves further research.

In conclusion, Posidonia oceanica is a much more important source of organic carbon for littoral Mediter- ranean food webs than previously believed, and any decline in the extension of seagrass beds may negatively affect not only seagrass-dwelling species, but also those from adjoining ecosystems.

Acknowledgements. The samples from Caretta caretta and Stenella coeruleoalba were provided by the BMA tissue bank, with the support of the Pew Fellows Program in Marine Conservation and Earthtrust. These samples were analyzed under the Life project 'Protección de Praderas de Posidonia en LICs de Baleares' LIFE 2000/NAT/E/7303 and the project BOS2003-05904 of the Spanish Government (CICYT). M. Sales was supported by Institut Menorquí d'Estudis. P. Manent assisted in field work. F. de Pablo supplied the samples of Phalacrocorax aristotelis and R. Triay supplied Pandion haliaetus samples.

\section{LITERATURE CITED}

Aguilar A (2000) Population biology, conservation threats and status of Mediterranean striped dolphins (Stenella coeruleoalba). Cetacean Res Manage 2:17-26

Andersen V, Nival P (1988) A pelagic ecosystem model simulating production and sedimentation of biogenic particles: role of salps and copepods. Mar Ecol Prog Ser 44:37-50

Banaszak AT, Iglesias-Prieto R, Trench RK (1993) Scrippsiella velellae sp. nov. (Peridiniales) and Gloeodinium viscum sp. nov. (Phytodiniales), dinoflagellate symbionts of two hydrozoans (Cnidaria). J Phycol 29:517-528

Blanco C, Salomón O, Raga JA (2001) Diet of the bottlenose dolphin (Tursiops truncatus) in the Western Mediterranean Sea. J Mar Biol Assoc UK 81:1053-1058

Boudouresque C-F, Meinesz A, Ledoyer M, Vitello P (1994) Les herbiers à Phanerógames marines. In: Bellan-Santini D, Lacaze JC, Poizat C (eds) Les biocénoses marines et litorales de Méditerranée, synthèse, menaces et perspectives. Museum National d'Histoire Naturelle, Paris, p 98-118

Cardinale M, Colloca F, Ardizzone GD (1997) Feeding ecology of Mediterranean razorfish Xyrichthys novacula (L. 1758 ) in the Tyrrhenian Sea (Central Mediterranean Sea). J Appl Ichthyol 13:105-111

Cardona L, Revelles M, Carreras C, San Félix M, Gazo M, Aguilar A (2005) Western Mediterranean immature loggerhead turtles: habitat use in spring and summer assessed through satellite tracking and aerial surveys. Mar Biol 147:583-591

Cebrián J, Duarte C, Marbà N, Enriquez S, Gallegos M, Olesen B (1996) Herbivory on Posidonia oceanica: magnitude and variability in the Spanish Mediterranean. Mar Ecol Prog Ser 130:147-155

Cebrián J, Duarte C, Marbà N, Enriquez S (1997) Magnitude and fate of the production of four co-occurring western Mediterranean seagrass species. Mar Ecol Prog Ser 155: 29-44

Créach M, Schrike MT, Bertru G, Mariotti A (1997) Stable isotopes and gut analyses to determine feeding relationships in saltmarsh macroconsumers. Estuar Coast Shelf Sci 44: $599-611$

Cruzado A (1985) Chemistry of Mediterranean water. In: Margalef R (ed) The western Mediterranean. Pergamon Press, London, p 126-146

Currin CA, Newell SY, Paerl HW (1995) The role of standing dead Spartina alterniflora and benthic microalgae in salt 
marsh food webs: considerations based on multiple stable isotopes analysis. Mar Ecol Prog Ser 212:99-116

Dauby P (1989) The stable carbon isotope ratios in benthic food webs of the Gulf of Calvi, Corsica. Cont Shelf Res 9: 181-195

Dauby P, Bale AJ, Bloomer N, Canon C and 7 others (1995) Particle fluxes over a Mediterranean seagrass bed: a one year case study. Mar Ecol Prog Ser 16:233-246

DeNiro MJ, Epstein S (1977) Mechanism of carbon isotope fractionation associated with lipid synthesis. Science 197: 261-263

Duarte CM, Cebrián J (1996) The fate of marine autotrophic production. Limnol Oceanogr 41:1758-1766

Duggins DO, Simenstad CA, Estes JA (1989) Magnification of secondary production by kelp detritus in coastal marine ecosystems. Science 245:170-173

Emelyanov EM (1972) Principal types of recent bottom sediments in the Mediterranean Sea: their mineralogy and geochemistry. In: Stanley DJ (ed) The Mediterranean Sea: a natural sedimentation laboratory. Dowden, Hutchinson \& Ross, Stroudsburg, p 355-386

Fantle MS, Dittel AI, Schwalm SM, Epifanio CE, Fogel ME (1999) A food web analysis of the juvenile blue crab, Callinectes sapidus, using stable isotopes in whole animals and individual amino acids. Oecologia 120:416-426

France RL, Peters RH (1997) Ecosystem differences in the trophic enrichment of ${ }^{13} \mathrm{C}$ in aquatic food webs. Can J Fish Aquat Sci 54:1255-1258

Francour P, Thibault JC (1996) The diet of breeding osprey Pandion haliaetus on Corsica: exploitation of a coastal marine environment. Bird Study 43:129-133

Gaye-Siessegger J, Focken U, Muetzel S, Hansjörg A, Becker K (1999) Feeding level and individual metabolic rate affect $\delta^{13} \mathrm{C}$ and $\delta^{15} \mathrm{~N}$ values in carp: implications for food web studies. Oecologia 138:175-183

Gonzalvo J, Aguilar A (in press) Photo-identification of bottlenose dolphins (Tursiops truncatus) in the Balearic Islands. Eur Res Cetaceans

Iglesias M, Massutí E, Reñones O, Morales-Nin B (1994) Three small-scale fisheries based on the island of Majorca (NW Mediterranean). Boll Soc Hist Nat Balears 37:36-58

Jennings S, Reñones O, Morales-Nin B, Polunin NVC, Moranta J, Coll J (1997) Spatial variation in the ${ }^{15} \mathrm{~N}$ and ${ }^{13} \mathrm{C}$ stable isotope composition of plants, invertebrates and fishes on Mediterranean reefs: implications for the study of trophic pathways. Mar Ecol Prog Ser 146:109-116

Kikinger R (1986) Development cycle of Cotylorhiza tubercolata (Scyphozoa: Rhizostomae). Nova Thalassia 8 (Suppl 2):73-82

Lepoint G, Nyssen F, Gobert S, Dauby P, Bouquegneau JM (2000) Relative impact of a seagrass bed and its adjacent epilithic algal community in consumer diets. Mar Biol 136: 513-518

Loneragan NR, Bunn SE, Kellaway DM (1997) Are mangroves and seagrasses sources of organic carbon for penaeid shrimps in a tropical Australian estuary? A multiple stable-isotope study. Mar Biol 130:289-300

Malej A (1989) Behaviour and trophic ecology of the jellyfish Pelagia noctiluca (Forsskål, 1775). J Exp Mar Biol Ecol 126:259-270

Massutí E, Reñones O, Carbonell A, Oliver P (1996) Demersal fish communities exploited on the continental shelf slope off Majorca (Balearic Islands, NW Mediterranean). Vie Milieu 46:45-55

Mateo MA, Romero JA (1997) Detritus dynamics in the seagrass Posidonia oceanica: elements for an ecosystem carbon and nutrient budget. Mar Ecol Prog Ser 151:43-57
McCutchan JH, Lewis WM, Kendall C, McGrath C (2003) Variation in trophic shift for stable isotope ratios of carbon, nitrogen, and sulfur. Oikos 102:378-390

Mejías R, Amengual J (2000) Libre vermell dels vertebrats de les Balears. Conselleria de Medi Ambient, Palma de Mallorca

Michener RH, Schell DM (1994) Stable isotope ratios as tracers in marine aquatic food webs. In: Lajtha K, Michener $\mathrm{RH}$ (eds) Stable isotopes in ecology and enviromental science. Blackwell Scientific Publications, Oxford, p138-157

Minagawa M, Wada E (1984) Stepwise enrichment of ${ }^{15} \mathrm{~N}$ along food chains: further evidence and the relation between $\delta^{15} \mathrm{~N}$ and animal age. Geochim Cosmochim Acta 48:1135-1140

Morte S, Redon MJ, Sanz Brau A (1999) Feeding habits of Trachinus draco off the eastern coast of Spain (Western Mediterranean). Vie Mileu 49:287-291

Ogawa N, Ogura N (1997) Dynamics of particulated organic matter in the Tamagawa estuary and inner Tokyo bay. Estuar Coast Shelf Sci 44:263-273

Oro D, Ruiz X (1997) Seabirds and trawler fisheries in the northwestern Mediterranean: differences between the Ebro Delta and the Balearic Is. areas. ICES J Mar Sci 54: 695-707

Paterson AW, Whitfield, AK (1997) A stable carbon isotope study of the food-web in a freshwater-deprived South African estuary, with particular emphasis on the ichthyofauna. Estuar Coast Shelf Sci 45:705-715

Peirano A, Niccolai I, Mauro R, Bianchi CN (2001) Seasonal grazing and food preference of herbivores in a Posidonia oceanica meadow. Sci Mar 65:367-374

Pérez-Ruzafa A, Gilabert J, Gutierrez J, Fernández A, Marcos S, Sabah S (2002) Evidence of a planktonic food-web response to changes in the nutrient input dynamics in the Mar Menor coastal lagoon, Spain. Hydrobiologia 475/476: 359-369

Phillips DL, Gregg J W (2003) Source partitioning using stable isotopes: coping with too many sources. Oecologia 136: 261-269

Pinnegar JK, Polunin NVC (2000) Contributions of stableisotope data to elucidating food webs of Mediterranean rocky littoral fishes. Oecologia 122:399-409

Polunin NVC, Morales-Nin B, Pawsey WE, Cartes JE, Pinnegar JK, Moranta J (2001) Feeding relationships in Mediterranean bathyal assemblages elucidated by stable nitrogen and carbon isotope data. Mar Ecol Prog Ser 220: 13-23

Procaccini G, Buia MC, Gambi MC, Perez M, Pergent G, Pertent-Martini C, Romero J (2003) The seagrasses of the western Mediterranean. In: Green EP, Short FT (eds) World atlas of seagrasses. University of California Press, Berkeley, CA, p 48-58

Reñones O, Massutí E, Morales-Nin B (1995) Life history of red mullet (Mullus surmuletus) from the bottom trawl fishery off Majorca Island (NW Mediterranean). Mar Biol 123: 411-419

Riera F, Linde M (2001) El raor i la cirviola. Conéixer per preservar. Conselleria d'Agricultura i Pesca, Palma

Roux C (1986) Dactylopteridae. In: Whitehead PJP, Bauchot JC, Hureau ML, Nielsen J, Tortonese E (eds) Fishes of the North-eastern Atlantic and the Mediterranean, Vol 2. UNESCO, Paris, p 1284-1285

Salat J (1996) Review of hydrographic environmental factors that may influence anchovy habitats in the northern Mediterranean. Sci Mar 60 (Suppl 2):21-32

Sarà G, Vizzini S, Mazzola A (2003) Sources of carbon and dietary habits of new Lessepsian entry Brachidontes 
pharaonis (Bivalvia, Mytilidae) in the western Mediterranean. Mar Biol 143:713-722

Stergiou K, Karpouzi VS (2002) Feeding habits and trophic levels of Mediterranean fish. Rev Fish Biol Fish 11: $217-254$

Suchanek TH, Williams SL, Ogden JC, Hubbard DK, Gill IP (1985) Utilization of shallow-water seagrass detritus by Caribbean deep-sea macrofauna: $\delta^{13} \mathrm{C}$ evidence. DeepSea Res 32:201-214

Tomás J, Aznar FJ, Raga, JA (2001) Feeding ecology of the loggerhead turtle Caretta caretta in the western Mediterranean. J Zool Soc Lond 255:525-532

Tomas F, Turon X, Romero J (2005) Seasonal and small-scale spatial variability of herbivore pressure on the temperate seagrass Posidonia oceanica (L.) Delile. Mar Ecol Prog Ser 301:95-107

Tomas F, Álvarez-Cascos D, Turon X, Romero J (2006) Differ-

Editorial responsibility: Kenneth Heck (Contributing Editor), Dauphin Island, Alabama, USA ential element assimilation by sea urchins Paracentrotus lividus in seagrass beds: implications for trophic interaction. Mar Ecol Prog Ser 306:125-131

Triay R (2002) Seguimiento por satellite de tres juveniles de águila pescadora nacidos en Menorca. Ardeola 49: 249-257

Vanderklift MA, Ponsard S (2003) Sources of variation in consumer-diet $\delta^{15} \mathrm{~N}$ enrichment: a meta-analysis. Oecologia 136:169-182

Vetter EW, Dayton PK (1999) Organic enrichment by macrophyte detritus, and abundance patterns of megafaunal populations in submarine canyons. Mar Ecol Prog Ser 186: $137-148$

Vizzini S, Mazzonal A (2003) Seasonal variations in the stable carbon and nitrogen isotope ratios $\left({ }^{13} \mathrm{C} /{ }^{12} \mathrm{C}\right.$ and $\left.{ }^{15} \mathrm{~N} /{ }^{14} \mathrm{~N}\right)$ of primary producers and consumers in a western Mediterranean coastal lagoon. Mar Biol 142:1009-1018

Submitted: October 3, 2005; Accepted: September 27, 2006 Proofs received from author(s): April 5, 2007 